\title{
The business capacity of broiler farmers in the partnership business pattern
}

\author{
R. Suryanti ${ }^{1,4}$, S. Sumardjo ${ }^{2 *}$, S. Syahyuti ${ }^{3}$ and P. Tjitropranoto ${ }^{2}$ \\ ${ }^{1}$ Study Program of Communication Science and Community Development, \\ Department of Communication Science and Community Development, \\ Faculty of Human Ecology, Graduate School, IPB University, West Java - 16680 - Indonesia \\ ${ }^{2}$ Department of Communication Science and Community Development, \\ Faculty of Human Ecology, IPB University, West Java 16680 - Indonesia \\ ${ }^{3}$ Center for Agricultural Economics and Policy, Secretariat General of the Ministry of Agriculture \\ Agricultural Research Complex, Cimanggu Bogor, West Java - Indonesia \\ ${ }^{4}$ Bogor Agricultural Development Polytechnic, PPSDMP Agency, Ministry of Agriculture, \\ Jl. Arya Suryalaga (d/a Cibalagung), No. 1 Bogor, West Java 16001 - Indonesia \\ *CorrespondingE-mail: sumardjo252@gmailcom
}

Received April 05, 2019; Accepted July 19, 2019

\begin{abstract}
ABSTRAK
Penelitian dilakukan untuk menganalisis tingkat kapasitas berusaha peternak ayam ras pedaging pada pola usaha kemitraan dan faktor yang mempengaruhinya. Penelitian dilaksanakan di Kabupaten Bogor dan Kabupaten Sukabumi Provinsi Jawa Barat dengan pendekatan survey terhadap 247 peternak yang menjalankan usaha peternakan dengan pola kemitraan. Data dikumpulkan melalui pengisian kuisioner oleh peternak serta wawancara mendalam terhadap informan kunci. Pengambilan data dilakukan pada bulan Juli sampai dengan Oktober 2018. Analisis data menggunakan analisis deskriptif dan inferensia (regresi). Hasil penelitian menunjukkan bahwa kapasitas berusaha peternak lemah. Hal ini terlihat dari kemampuan manajerial dan kemitraan terkategori rendah, kemampuan kewirausahaan dan mengatasi masalah terkategori sedang dan hanya kemampuan teknis terkategori tinggi. Penyuluhan oleh swasta fokus pada teknik budidaya sehingga kemampuan teknis tinggi. Rendahnya kemampuan manajerial dan kemitraan menyebabkan peternak sulit untuk mengembangkan usaha. Hasil regresi memperlihatkan bahwa kapasitas berusaha dipengaruhi secara positif oleh tingkat pendidikan formal, karakteristik lingkungan sosial (dukungan organisasi, akses tenaga ahli), dan peran penyuluh swasta (peran sebagai edukator, komunikator, konsultan, dinamisator dan organisator).
\end{abstract}

Kata kunci: kapasitas berusaha, kemitraan, peran penyuluh swasta, peternak ayam

\begin{abstract}
The present study was conducted to analyze the broiler farmers' capacity level in the partnership pattern and to analyze the factors which affect it. The current study was conducted in Bogor and Sukabumi, West Java Province using a survey approach on 247 farmers who ran farm businesses with the partnership pattern. Data were collected through questionnaire filling by farmers and in-depth interviews with key informants. The data were collected from July to October 2018. The data were analyzed descriptively and with inferential analysis (regression). The results of the study revealed that the farmers' business capacity was weak. This was evident in the managerial and partnership capability which was categorized as low, the entrepreneurship and problem-solving capability which was
\end{abstract}


categorized as medium, and only the technical capability which was categorized as high. The regression results demonstrated that business capacity was influenced positively by the formal education level, social environment characteristics (organizational support, access to experts), and the role of private extension agents (their role as educators, communicators, consultants, dynamizators, and organizers).

Keywords: broiler farmer, business capacity, partnership, private extension agents' role

\section{INTRODUCTION}

The farmers' low business capability is a problem that threatens the business sustainability of broiler farms. The current condition indicates that broiler farmers have a low business capacity. This is evident in the general issues that arise in this business, namely the lack of cultivation skills (Durgga and Subhadra, 2009; Bhattu et al., 2015), the limited knowledge of diseases (Anang et al., 2013; Kumar et al., 2013; Ali et al., 2015; Bhattu et al., 2015; Mehdi et al., 2018), the lack of innovation in running the agribusiness (Anang et al.,2013; Mbuza et al., 2016), the lack of understanding of the partnership contract (Indarsih et al., 2010; Kalio and Okafor, 2012), the farmers' weak entrepreneurship, Butterworth, 2013; Bounds and Zinyemba, 2016) and possibilities of conflict with the adjacent community (Henderson 2005). When classified, these issues could be grouped as technical aspect issues, managerial aspect issues, entrepreneurship aspect issues, and partnership execution issues. These limitations have caused the farmers to face difficulties in running their business well in order to obtain optimum results.

To date, the broiler farm business is a business run by many Indonesians. The Central Bureau of Statistics (BPS, 2012) recorded that 77,147 farmer households are involved in this business with the highest population of farmers in West Java. The large number of farmers and the high population of livestock is related to the fact that broiler meat is a source of animal protein which is relatively affordable and popular with consumers (Beski et al., 2015). The population of broilers in 2017 was 1,698,369, which increased compared to the population in 2013 which was $1,344,191$ birds. The increase in population was proportionate with the increase in broiler meat consumption. The consumption of broiler meat in 2013 was $3.650 \mathrm{~kg}$ per capita per year, while in 2017 the consumption reached $5.68 \mathrm{~kg}$ per capita per year (BPS, 2018).

Broiler farms in Indonesia are mostly small-scale farms of which many are run using a partnership pattern. The partnerships bring benefits for both the farmers and the core companies. The benefit for the farmers is that it helps overcome the issues of capital for running the business because the broiler farm business requires a relatively large business capital. The partnership pattern is popular with farmers because the partnership assists the farmers in obtaining production facilities that require a large amount of capital. The benefit of the partnership pattern for the core companies is related to the companies' production target. The partnerships run by the core company are an effort to bridge the production gap, the gap between the companies' production capability and the companies' production target.

The consequences of a partnership are that the core company is required to provide guidance to the plasma farmers by conducting supervisions and extension which are handled by private extension agents. As extension activities, one of the goals that should be the aim of the supervision by the core company is the improved capability of the farmers in running their business so that business sustainability could be achieved. The development of small-scale farms is strongly dependent on the business capacity possessed by the farmers. Business capacity here is defined as the ability possessed by farmers in running the broiler farm business. This concept refers to the explanation pertaining to capacity which describes capability, the innate capacity in a person to conduct a certain function in the effort to reach a goal. The current study was aimed to analyze the broiler farmers' capacity level in the partnership pattern and to analyze the factors which affect it.

\section{MATERIALS AND METHODS}

The study was conducted in Bogor Regency and Sukabumi Regency which are the broiler development areas in West Java. Data collection in the field was conducted from July to October 2018. The current study was designed using a quantitative approach enriched by qualitative data. The collection of quantitative data was conducted using the survey method on 247 partnership 
farmers distributed in Bogor Regency and Sukabumi Regency. The determination of the number of samples used the Slovin technique on the farmer population which consisted of 646 people in the two regencies. The determination of the number of samples in each regency was done proportionately based on the number of the population in each regency. Based on the proportional calculation, the number of samples in Bogor Regency was 110 people and in Sukabumi Regency 137 people. The qualitative data were collected through in-depth interviews with key informants and observations of field conditions. In addition to primary data obtained from the respondents and key informants, secondary data were also collected through the perusal of documents and manuscripts related to the effort to achieve the study purposes.

\section{Individual Characteristic Variable (X1)}

Age (the total number of years starting from the respondent was born until the present study was conducted $=$ it was measured in years, was ratio data); Formal education (the number of years spent attending school and university, it was measured in years as the ratio data); Non-formal education (the frequency of courses, training programs, upgrading programs attended by the respondent until the survey was conducted $=$ it was measured as categories of low, medium, high, very high was ordinal data which was to be transformed into interval data); Income (the average amount of income per month. Sources of income $=$ it was measured in rupiah as the ratio data); Business experience (the number of years the respondent had spent in the broiler business. The business type/pattern applied $=$ it was measured in years as the ratio data); Business scale (the number of broilers kept during the time of the study. The size of the broiler house = measured in number of individuals as the ratio data, measured in square meters as the ratio data); Cosmopolitanism $=$ the size of the network between the farmer and people outside of the village that was measured in categories low, medium, high, very high $=$ ordinal data which was to be converted into interval data).

\section{Social Environment Characteristic (X2)}

Socio-cultural values (the level of suitability between the socio-cultural values and the farming business, openness, mutual cooperation (gotong royong), respecting the local people's interests); Family member involvement (the intensity of which the family members give input in planning, the number of family members working in running the farming business); Community elder influence ( the level of support given by formal community elders to the farming business, the support of non-formal community elders given to the farming business, the involvement of community elders in farmer meetings); Farmer organization support (the level of openness of the organizational management, the level of effectiveness of the presence of the organization to the farming business, the level of usefulness of the organization for the farmers); Economic asset ownership (land ownership,transportation ownership, farming equipment ownership, broiler house ownership); Access to experts (government institutions) (the frequency of which the farmers meet and ask for assistance from farming technical personnel when encountering difficulties, the level of usefulness of the technical institutions (UPTD, Government agencies) to the farmers, the level of usefulness of the research institutions (their research results) for the farmers); Market conditions (Competition with other farmers Fulfillment of product quality standards); Perceptions of partnership (Contract and agreement contents, the role of partnership parties, the core company's stance, sanctions, the economic benefits of the partnership, the advantages and disadvantages of the partnership pattern). Measured using an ordinal scale consisting of four levels based on the total score.

\section{Information Sources (X3)}

Government extension agents (type of information, interaction frequency); Independent extension agents (type of information, Interaction frequency); Conventional media (type of medium, type of information, interaction frequency); Cybermedia (type of medium, type of information, interaction frequency). Measured using an ordinal scale consisting of four levels based on the total score.

\section{The Role of Private Extension Agents (X4)}

Educator (Providing supervision, knowledge, skills, and aptitude Coaching the farmers in problem-solving, learning while working, utilizing various resources for learning, developing the habit of learning from experience); Communicator (The farmers' perception of private extension agents in managing communication, guiding the networking system, utilizing communication media); Consultant 
(Identifying and analyzing problems, giving advice and considerations, recommending solutions to problems related to the broiler agribusiness); Motivator (Nurturing the farmers' spirit and burying their weaknesses, building empathy, helping the farmers achieve success, understanding the farmers' needs, setting certain standards or targets, encouraging the farmers to rise from their failures); Facilitator (facilitating the communication process so that an understanding is built and problems could be solved together, connecting the farmers with parties concerned with the development of farming businesses, becoming a mediator in any conflict that arises); Dynamizator (Building a good rapport with the farmers, community, and government officials, nurturing a conducive condition); Organizer (The farmers' perception of the extension agent's ability to manage extension activities, build a healthy relationship with the community, build awareness). Measured using an ordinal scale consisting of four levels based on the total score.

\section{Farmer Capacity (Y)}

Technical capability (broiler house and equipment preparation determining the DOC strain Feeding and vaccine dosages Providing safety and comfort for the broilers, determining the harvesting age and method Post-harvest handling); managerial capability (Operational capability, human resources-managing capability, marketing capability, financial managing capability, negotiation and communication capability); entrepreneurship capability (courage in taking risks, ability to innovate, capability to utilize chances, diligence in business); partnership capability ( selecting the core company to partner with planning the agreement, understanding the contract, implementing the contract consistently); problem-solving (Aware of information and innovations related to the problems faced, the ability to learn from their personal experience and other people's experience in solving problems, creativity in making business decisions that are more advantageous). Measured using an ordinal scale consisting of four levels based on the total score.

A descriptive analysis was conducted to determine farmers' capacity in running their broiler business. Inferential analysis using multiple linear regressions was used to describe the factors that influenced their capacity. The model was developed based on the hypothesis that the farmers' capacity was influenced by the farmers' characteristic factors which included age (X11), the farmers' formal education (X12), the farmers' income (X13), farming experience in years (X14) , broiler population (X15), and cosmopolitan level (X16), social environment (X2), information sources (X3), and the role of private extension agents (X4). After the regression results were obtained based on the hypothesis above, the analysis was continued with a subvariable regression analysis of the factors significant to the capacity level.

\section{RESULTS AND DISCUSSION}

\section{Farmers' Capacity Level}

The farmers' capacity was still weak; this was evident from the score mean that did not reach $80 \%$ (Table 1 ). The weak capacity was apparent from the managerial and partnership capability which was categorized as low, the entrepreneurship and problem-solving capability which was categorized as medium, and only the technical capability was categorized as high (Table 1).

Less than $1 \%$ of the farmers had low technical capability. The farmers in this category found it difficult to follow the instructions given by the private extension agents because they had a tendency to adhere to their own habit in running their business. The partnership contract that they had signed did little to encourage the farmers to follow the private extension agents' suggestions. This group of farmers usually required proof before they were willing to follow any technical suggestions. The farmers in this category were farmers with a large population (>15.000 broilers) and farmers who have run a broiler farm for many years (23.6 - 31 years). Private extension agents' experience showed that new farmers and farmers with smaller populations $(<5.000$ broilers $)$ were more malleable to the application of technology. Large farm owners and those with extensive experience were rather difficult to handle because they demanded proof. It was conveyed that when given new knowledge and technology in running the business, large farm owners still questioned the appropriateness of the innovation and the business profits they would gain. Their attitude is understandable as the risk they face by applying less than appropriate technology is greater than that of smaller farm owners.

This condition differs from the technical capability which is they capability most mastered 
Table 1. Farmer Respondent Distribution Based on the Farmers' Capacity

\begin{tabular}{llc}
\hline Farmers' capacity & Category & Percentage \\
\hline Technical capability & Very low & 0.4 \\
(mean 81.6) & Low & 0.4 \\
& Medium & 21.1 \\
& High & 78.1 \\
Managerial & Very low & 13.4 \\
(mean 48.2) & Low & 53.0 \\
& Medium & 27.5 \\
& High & 6.1 \\
Entrepreneurship & Very low & 2.0 \\
(mean 63.5) & Low & 25.1 \\
& Medium & 55.9 \\
Partnership & High & 17.0 \\
(mean 48.8) & Very low & 5.3 \\
& Low & 54.3 \\
& Medium & 34.4 \\
Problems & High & 6.1 \\
(mean 60.3) & Very low & 1.6 \\
& Low & 17.8 \\
& Medium & 69.2 \\
& High & 11.3 \\
& & 60.5 \\
\hline
\end{tabular}

by the farmers (Table 1). The farmers already have a good understanding of good broiler houses conditions, the equipment they should use, and technical issues related to broiler husbandry. Observation results revealed that the farmers had good broiler houses, the broiler houses were positioned higher than the surrounding land, and the broiler houses positions allowed maximum air circulation and sunlight exposure. The private extension agents who were interviewed explained that the husbandry technical knowledge possessed by the farmers was adequate even though they have not fully adopted the most recent technology. In the broiler housing aspect, for instance, the farmers mostly used broiler houses raised on stilts, not on the ground, even though the most recent recommended technology was the closed house system. A similar assessment was given by the Extension Agent Coordinator of the Bogor Regency Animal Husbandry Agency (Baliyan and Marumo, 2016).

The percentage of farmers with a low entrepreneurship capability was $27.1 \%$. This indicated that some of the farmers were not yet able to handle risks, innovate, and make use of opportunities. Farmers with a small livestock population tended to be passive in observing opportunities and lacked the courage to take risks. They merely ran their businesses without any desire to develop, were unwilling to take any risks, and had low innovation power. Their concern was the unstable condition of the farming business. When farmers received high-quality DOC supported by high-quality feed, they felt optimistic about the business they run. This state is not consistent, there are times when the quality of the DOC and the feed is low, threatening the productivity and profit; issues they face in running the business.

The ability to innovate and utilize opportunities tended to be shown by farmers with a larger business scale whom some had the characteristics of having intermediate to higher education, being relatively young, and being open-minded with a high cosmopolitan level. A number of farmers encountered in Pamijahan, Ciampea, Ciawi, Dramaga, and Pelabuhan Ratu were examples of farmers with high entrepreneurship, characterized by a relatively young age, having high school and university education, and being open-minded. They had the courage to innovate, take risks, and make use of opportunities. The innovations they usually made were utilizing local wisdom. They concocted herbal supplements to help maintain their broilers' condition and to stimulate growth using the plants available around the farm. For example, they used a concoction of Javanese ginger (Curcuma zanthorrhiza), guava leaves, and palm sugar to improve broiler production (Mahmoud et al., 2013; Al-Ramamneh, 2018). The use of supplements increased the production cost but was judged to be beneficial and profitable by the farmers. The core companies did not object to the use of these concoctions as long as they had a positive effect on broiler production.

Farmers who were categorized as progressive farmers were quick to take risks and make use of opportunities. The steps taken by the farmers led to a more resilient business and a relatively more stable profit. This was supported by Morris et al. (2017) who stated that farmers 
who have a high entrepreneurship capacity are able to face challenges in life to make use of opportunities with the various risks they might face, achieving value through innovation and economic activity expansions by identifying and utilizing new products, processes, and markets.

Some farmers in Pamijahan formed a farmer community initiated by a farmer who was also a community elder in that area. Another farmer in Tenjolaya integrated farm extensions into farmer group activities in this village. The farmer group and community activities were still very limited, and the utilization of the group as a medium to learn and improve production activities was very lacking. In other areas, groups and communities were not found, so it could be said that the relationship among farmers tended to be very limited. The limited communication prevented the technology and information possessed by one farmer from spreading to other farmers. Farmers from the same partnership companies did not know each other because there was no medium for them to interact and share.

A small percentage of farmers (less than $20 \%$ ) had the ability to solve problems which was categorized as low (Table 1). This indicated that the farmer had yet to solve the problems faced in running the business. The farmers in this category relied on private extension agents for problemsolving. The regular visits from private extension agents every week and the guidance they provided were very useful for farmers to help give solutions in running the business.

In general, the farmers were quite capable of overcoming problems in the broiler farm (Table 1). This ability was developed due to the wealth of information from fellow farmers, help from private extension agents, and their personal experience. In a single year, broiler farms could go through five or six production periods. The various conditions they faced in every period enriched the farmers' experience. Moreover, the issues that this business faced tended to repeat with little variation. These problems included broiler health issues, biosecurity, the low quality of livestock production facilities, and other issues pertaining to the technical aspect of husbandry and partnership. Younger farmers overcame the technical problems by searching for information from cyber media and by discussing the issues with other farmers in addition to consulting with private extension agents.

\section{Factors that Influenced the Broiler Farmers' Business Capacity}

The farmers' business capacity was positively influenced by formal education, social environment characteristics, and the role of private extension agents but was negatively influenced by information sources (Table 2). The mathematical equation for the factors which influenced the farmers' business capacity could be formulated as follows:

Business capacity $=6.013+0.12$ formal education +0.16 social environment characteristics $\quad-0.21$ farmers's information sources +0.44 role of private extension agents

The analysis results revealed that the value of $\mathrm{R}^{2}$ was 0.49 . This value showed that the ability of the independent variables in influencing (predicting) dependent variables was $49.1 \%$.

Formal education is a person's capital in running a business, which is why formal education had a significant effect on the farmers' business capacity (Table 2). This encourages farmers to have adequate capacity. Farmers who had more formal education had better ability in analyzing the situation, were more open-minded, and were capable of utilizing opportunities. Farmers with higher education were the embodiment of farmers with adequate ability in the business (Mendes et al., 2014). Some of the farmers who had businesses on a fairly large scale and were classified as successful farmers were those with higher education (associate's degree and bachelor's degree holders).

Organizational support and access to experts were the characteristics of the social environment needed by farmers to improve their capacity in running their business (Table 3). Generally, the farmer did not join any farmer groups that specifically dealt with the broiler farming business. Some farmers were members of broiler farmer communities and some were members of farmer group organizations where one of the businesses dealt with was broiler farming.

This finding demonstrated that organizational support was important for the improvement of the farmers' capacity. Improvement of farmers' capacity through organizations was valuable for farmers because by joining group discussions, the farmers would widen their horizons and glean much information. A number of studies have demonstrated the importance of organizational support for the development of agribusinesses. In addition to 
Table 2. The Results of the Linear Regression Test of Factors Influencing the broiler Farmers' Business Capacity

\begin{tabular}{lcc}
\hline \multicolumn{1}{c}{ Factors } & B Coefficient & Significance \\
\hline Age & 0.06 & 0.340 \\
Formal education & $0.117^{*}$ & 0.039 \\
Income & -0.05 & 0.446 \\
Experience in running the business & -0.08 & 0.181 \\
Business scale & 0.03 & 0.649 \\
Cosmopolitan level & 0.06 & 0.262 \\
Social environment & $0.16^{* *}$ & 0.006 \\
Sources of information & $-0.21^{* *}$ & 0.000 \\
The role of private extension agents & $0.44^{* *}$ & 0.000 \\
\hline
\end{tabular}

** significantly different $\operatorname{sig}(\mathrm{p}<0.01)$, significantly different $\operatorname{sig}(\mathrm{p}<0.05)$

being a learning medium, organizations are a medium for farmers to have access to and develop the market. This is in line with the governments' policy in improving farmer abilities through the strengthening of farmer institutions (Baliyan and Marumo, 2016).

Sources of information consisting of government extension agents, conventional media, and cyber media simultaneously had a negative effect on the improvement of farmers' capacity. In the broiler farming business with the partnership pattern, the involvement of the private sector as the core company has led to intensive extension and supervision by private extension agents. This finding confirms that sources of information aside from private extension agents were unable to improve the farmers' business capacity. Information shared by government extension agents, conventional media, and cyber media proved to be unsuitable for the farmers in running the broiler business, so the information had no effect on the farmers. The topics often communicated by farmers with government extension agents were issues with permits, farmer data collection, and conflicts between farmers and the people living around the broiler houses, while farm technical issues were not addressed by government extension agents.

Conventional and cyber information media were usually accessed by farmers to monitor the prices and types of livestock production facilities, developments in market prices, and other technical issues. A plausible explanation is that the access by farmers to the two types of media did not fulfill the needs to improve farmers' capacity which included technical, managerial, entrepreneurship, partnership, and problemsolving capability. Access to the two types of media tended to fulfill the farmers' technical capability aspect but did not improve the other capacities, thus not having a positive cumulative effect on business capacity improvement.

Coaching in the broiler farming business was dominated by private extension agents. This caused the role of private extension agents to be very significant in improving the farmers' capacity (Table 3 ). This was supported by Yemane et al. (2016) who stated that the guidance received by farmers could improve their ability in managing production factors. The role of private extension agents as a communicator, consultant, disseminator, and organizer had a positive effect on their capacity (Frandsen et al., 2013; Platen, 2015). The role as an educator had a negative effect on the farmers' capacity. The negative effect here carried the meaning that the extension provided by private extension agents did not yet correspond to the learning principles in extension. Education in the extension context is an adult education approach which must prioritize individual needs. This means that the farmers' characteristics must be considered when conducting extension. The education should also be conducted in the effort for capacity building toward empowerment (Morris et al., 2017).

The positive effect of the private extension 
Table 3. The Regression Coefficient of Farmers Capasity Indicator Variable

\begin{tabular}{lcc}
\hline \multicolumn{1}{c}{ Influencing Factor } & $\beta$ Coefficient & Significance \\
\hline Social Environment & & \\
Farmer organization support & $0.35^{* *}$ & 0.000 \\
Access to experts & $0.26^{* *}$ & 0.000 \\
Source of Information & $0.20^{* *}$ & \\
Government extension agents & $-0.24^{* *}$ & 0.002 \\
Conventional media & $-0.17^{* *}$ & 0.000 \\
Cybermedia & & 0.007 \\
The Role of Private Extension Agents & $-0.14^{*}$ & \\
Educator & $0.29^{* *}$ & 0.015 \\
Communicator & $0.15^{*}$ & 0.000 \\
Consultant & $0.11^{*}$ & 0.014 \\
Dynamizator & $0.31^{* *}$ & 0.050 \\
Organizer & & 0.000 \\
\hline
\end{tabular}

** significantly different sig $(\mathrm{p}<0.01) .{ }^{*}$ significantly different $\operatorname{sig}(\mathrm{p}<0.05)$

agents' role as a communicator, consultant, dynamizator, and organizer and negative effect in the role as an educator demonstrated that the extension provided by private extension agents was limited to communicating technical guidelines, assisting in problem-solving, and facilitating the relationship with related parties but had not yet fully fulfilled the educating function during extension activities. Private extension agents were able to communicate matters that the farmers must conduct, especially technical matters. The private extension agents tried to assist farmers by giving guidelines and instructions in broiler farming. When facing problems, the farmers immediately contacted private extension agents. The private extension agents visited the farmers regularly, so the issues faced by the farmers could be discussed with the private extension agents. The private extension agents were capable of facilitating relationships with other parties to ensure the farms kept running. They also had good communication abilities with both farmers and the surrounding community, thus they were able to build a good rapport with both farmers and the nearby elders and community (Ofuoku, 2012; Nabinta et al., 2016).

\section{CONCLUSION}

The farmers' business capacity farmer was weak. Managerial and partnership capability was in a low category, problem-solving was in the medium category, while technical capability was high. The low business capacity was influenced by the low formal education level, the weak social environment characteristics and private extension agents' role, and the limited access to information.

\section{REFERENCES}

Ali, Y., S. Jahan, M. A. Islam and A. Islam. 2015. Impact of socio-economicfactors on production performance of small and medium size broiler farming in Bangladesh. J. Sci. Food Agric.15(1):479-487.

Al-Ramamneh, D. 2018. Effect of dietary combinations of garlic and onion in broiler production.Int. J. Poult. Sci. 17: 147-153.

Anang, B.T., A. A. Anthony and Y. Cosmos. 2013. Profitability of broiler and layer production in the bring Afro region of Ghana. ARPN J. Agric. Biol. Sci. 8(5):423-430.

Baliyan and D.S. Marumo. 2016. Analysis of farm management skills in small scale broiler poultry producers in Botswana. Int. J. Agr. Econ. Ext. 4(2):215-223. 
Beski, S. S. M., R. A. Swick and P.A. Iji. 2015. Specialized protein products in broiler chicken nutrition: A review. Anim Nutr. $1(2): 47-53$.

Bhattu, B.S., A. Sharma, and G. Singh. 2015. A Study on Constraints of Broiler Farming Entrepreneurship in Mansa District of Punjab. Int. J. Comput. Appl. 0975-8887: 24-27.

Bounds, M. and O. Zinyemba. 2018. Poultry farming: lessening poverty in rural areas. S. Afr. J. Agric. Ext. 46(1):59-70.

Butterworth, A. 2013. On-farm broiler welfare assessment and associated training. Braz J. Poult.Sci. 15(2):71-78.

Central Bureau of Statistics (BPS). 2018. Statistics of Poultry Farm. Jakarta, Indonesia.

Central Bureau of Statistics (BPS). 2012. Statistics of Poultry Farm. Jakarta, Indonesia.

Derbe, T. and N. Kavitha. 2016. Problems and prospects of poultry production in amhara region, ethiopia: a case analysis. RIJSS. 5(5):1-12

Durgga, R. V. and M.R. Subhadra. 2009. Problems related to farm operations in poultry farming as perceived by farm women. Vet. World. 2(5):191-192.

Frandsen, F., W. Johansen and A. Pang. 2013. From management consulting to strategic communication: studying the roles and functions of communication consulting. Int J. Strat Comm.7(2):81-83.

Henderson, S. R. 2005. Managing land-use conflict around urban centres: Australian poultry farmer attitudes towards relocation. Appl. Geogr. 25(2):97-119.

Indarsih, B., M. H. Tamsil and M. P. Nugroho. 2010. A Study of Contract Broiler Production in Lombok, NTB: An Opportunity of Introducing Syariah Partnership. Med. Pet. 33(2):124-130.

Kalio G. A., and B. B. Okafor. 2012. Response of Broilers to Two Management Systems of Housing in Etche Local Government Area of Rivers State, Nigeria. Asian J. Agric. Rural Dev. 2(2):184-188.

Kumar, S., N. Ramesh, S. Sreevatsan, M. Osterholm, B. Joseph, P. Alle and K. Belani. 2013. Knowledge, attitudes, and poultry-handling practices of poultry workers in relation to avian influenza in India. Indian. J. Occup. Environ. Med.
17(1):16 -21.

Mahmoud, R. E., D. Ibrahim and M.E. Badawi. 2013. Effect of supplementation of broiler diets with guava leaves and/or olive oil on growth, meat composition, blood metabolites and immune response. J. Vet. Med. Sci. 25(2):23-32.

Mbuza, F., R. Manishimwe, J. Mahoro, T. Simbankabo and K, Nishimwe. 2016. Characterization of broiler poultry production system in Rwanda. Trop Anim Health Prod. 49(1):71-77.

Mehdi, Y., M. P. Létourneau-Montminy, M.L. Gaucher, Y. Chorfi, G. Suresh, T. Rouissi, , S.K Brar, C. Cote, A.A. Ramirez and S. Godbout. 2018. Use of antibiotics in broiler production: Global impacts and alternatives. Anim. Nutr. 4(2):170-178.

Mendes, A.S.I., D.C.I. Gudoski., A.F.I.I Cargnelutti., E.J.I. Silva., E.H.I. Carvalho and G.M. Morello. 2014. Factors that Impact the Financial Performance of Broiler Production in Southern States of Paraná, Brazil. Braz. J. Poult. Sci. 16(1):113-120.

Morris, W., A. Henley and D. Dowell. 2017. Farm diversification, entrepreneurship and technology adoption: Analysis of upland farmers in Wales. J. Rural Studies. 53:132143.

Nabinta. R. T., A. R Tijjani and M. Muntaka. 2016. The Role of Extension Service in Risk Management in Poultry Production in Katsina Metropolis, Katsina State. J. Agric. Vet. Sci. 9(3):38-43.

Ofuoku, A.U. 2012. Influence of extension agents' and farmers' communications factors on the effectiveness poultry technology messages. TARE. 15(1): 14-23.

Platen, S.V. 2015. The communication consultant: an important translator for communication management. J. Manag. Commun. $19(2): 150-166$.

Soedjana, T. D. and A. Priyanti. 2017. Competitiveness of Indonesian Livestock Production among ASEAN Countries. Wartazoa. 27(1):001-014.

Yemane, N., B. Tamir and A. Mengistu. 2016. Constraints, opportunities and socioeconomic factors affecting flock size holding in small scale intensive urban poultry production in Addis Ababa, Ethiopia. Agric. Biol. J. N. Am. 7(3):146152. 